Kutlaca Dj. and S. Radosevic Innovation Capacity in the South East Europe Region', In Thomas Döring and Dietmar Sternad (eds) Handbook of Doing Business in South East Europe, Palgrave Macmillan, 2011

9

\title{
Innovation Capacity in the SEE Region
}

\author{
Đuro Kutlača and Slavo Radosevic
}

\section{Introduction}

A majority of the countries of SEE are so-called 'catching-up' economies. $<x e n>^{1}</ x e n>$ This basically means that their enterprises operate largely behind the technological frontier, by using the best available foreign technologies and by competing on the basis of production capability. However, catching up is not a process of mere imitation; it requires adaptation and innovation (Fagerberg and Verspagen, 2003; Fagerberg and Godhino, 2005). The capability to innovate remains essential, as no nation can 'free-ride' on the world scientific system (Salter and Martin, 2001). Economic catch-up in the twenty-first century places greater demands on the knowledge-related capabilities of the catching-up economies (Mowery, 2005, p. 30). The changing conditions surrounding the catching-up process make 'the role of indigenous public research more important today than it was in the 20th century' (Nelson, 2005, p. 19). Accordingly, assessing the innovation capacity of South East Europe is not an exercise in studying the future, but a quite important element for our understanding of the growth potential of this region in the medium and long term.

With the end of the Cold War, South East Europe became a new European periphery in terms of research and development (R\&D) and innovation. At the same time, it is a quite diverse periphery, which encompasses mainly catching-up economies (most of the countries in the region), two moderate innovators (Hungary and Greece) and one innovation follower (Slovenia; see below). $\langle\text { xen }\rangle^{2}</$ xen $>$ Although complete data are not available for many Western Balkan countries, it seems that differences between countries at different stages of catching up are substantial. This diversity is an important structural feature of the region and should have its advantages in terms of doing business. Differences in innovation capacities should enable multinational companies - including those from the region - to combine different levels of labour costs and technology into bundles of competitive products and services (Zysman and Schwartz, 1998). In addition, differences in technological levels and innovation capacities should represent some advantage for those lagging behind, as they can catch up through technical assistance and close interaction with their partners in more developed parts of the region. The question we want to address is whether these potential advantages have been exploited so far, and 
Kutlaca Dj. and S. Radosevic Innovation Capacity in the South East Europe Region', In Thomas Döring and Dietmar Sternad (eds) Handbook of Doing Business in South East Europe, Palgrave Macmillan, 2011

what SEE countries have done to exploit these opportunities. Competition is a dynamic process; enterprises and industries need to upgrade continually. So the issue is the level of innovation capacity in SEE countries and whether this level is improving. With this perspective in mind, the present chapter aims to assess the innovation capacity of SEE and its individual components, as well as issues pertaining to the integration of technology in SEE. First, we briefly explain the concept of national innovation capacity (NIC), which serves as our conceptual framework, and this is followed by an analysis of the position of the SEE countries in terms of their innovation capacity. The analysis will then be extended to cover issues of technology integration distinguishing between upstream integration (R\&D cooperation) and downstream integration - foreign direct investment (FDI) and production networks.

\section{National innovation capacity, growth and industrial upgrading in SEE}

There is a general consensus among economists that technological innovation plays a central role in the process of long-term economic growth. However, there is a wide variety of approaches when it comes to understanding the underlying drivers of growth and the innovation process itself. Aggregate presentations of technology innovation such as total factor productivity (TFP), or the part of growth which cannot be attributed to labour and capital, are not very useful, due to the overly aggregate nature of these indicators. In addition, it is not appropriate to consider physical capital, human capital and technology as separate factors. To think of them as separate from each other is a highly unrealistic assumption.

Innovation studies show that innovation does not result solely from one specific factor, for instance supply of R\&D (see Freeman and Soete, 1997 for an overview). In order to understand the key issues behind country differences in growth and technology, our analysis must be placed within a multi-dimensional framework - that is, one that captures several important dimensions, all of which determine innovation capacity (see Figure 9.1).

The development of an economy reflects the accumulation of its knowledge capital from micro-level (firm) to macro-level (national economy), as well as the institutional structuring of that capital through its national innovation system (NIS) (Lundvall, 1992). In this chapter, metrics are applied to identify potentials for development, which we conceptualize as national innovation capacity (NIC). A reader should be aware that any attempt to capture a highly multi-dimensional concept such as 'innovation capacity' into one composite indicator is inevitably subject to numerous objections. $<x e n>^{3}</$ xen $>$ However, we think that, in spite of the problems with this approach, the latter is still a useful and insightful exercise. SEE countries are at different stages of development insofar as technology and innovation are concerned, and these play quite diverse roles in growth and industrial upgrading. An overview of the different 
Kutlaca Dj. and S. Radosevic Innovation Capacity in the South East Europe Region', In Thomas Döring and Dietmar Sternad (eds) Handbook of Doing Business in South East Europe, Palgrave Macmillan, 2011

stages of technological development as well as of the factors by which they are determined should offer new insights, which are of relevance both for business and for spolicy makers.

The NIC approach enables us to look beyond R\&D to understand innovation capacity. In keeping with the national innovation system approach, the NIC approach measures indicators of innovation capacity organized into four groups: R\&D supply, absorptive capacity, diffusion and demand (see Table 9.1) - following the idea that the growth and innovation capacity of an economy depends not only on the supply of R\&D, but also on the capability of the country to absorb and diffuse technology, as well as on the demand for its generation and utilization. Individual elements of the framework are interrelated. In aggregation, they produce the national innovation capacity (Radosevic, 2004).

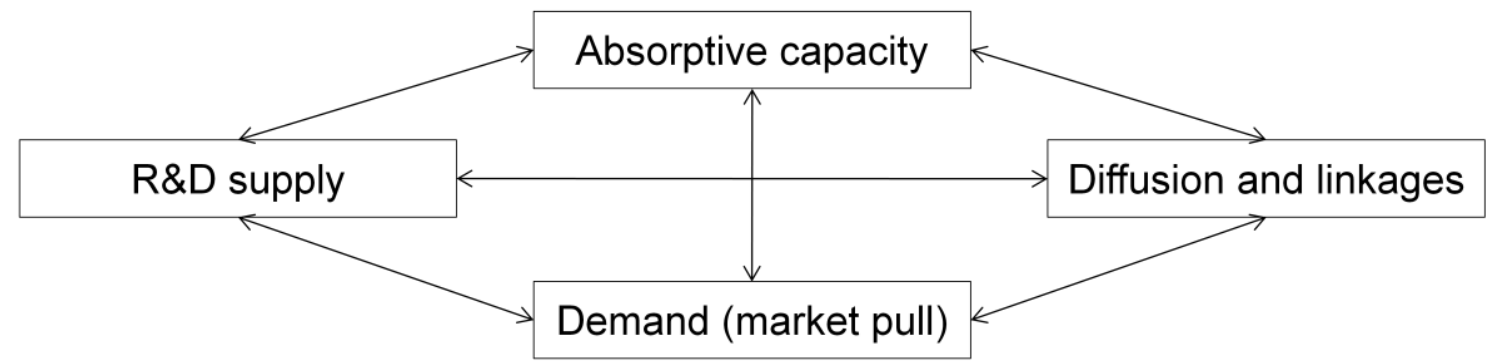

[Figure 9.1 The concept of national innovation capacity

Source: Radosevic (2004).

Table 9.1 indicators of innovation capacity

Name of indicator

Absorptive capacity

Expenditures in education in \% of GDP

Science and engineering graduates (\% 20-29 population)
Abbreviation Year Source

eductgdp 2007 Eurostat

segrdpop 2007 EIS 
Kutlaca Dj. and S. Radosevic Innovation Capacity in the South East Europe Region', In Thomas Döring and Dietmar Sternad (eds) Handbook of Doing Business in South East Europe, Palgrave Macmillan, 2011

Population with 3rd-level education

pop3educ $\quad 2008$ EIS

Participation in life-long learning (\% of working age population) llearng

2008 EIS

Employment in high-tech manufacturing

emplmdhtec 2008 EIS

Employment in high-tech services

emphsrvc

2008 EIS

R\&D supply

Public R\&D expenditures (\% of GDP)

pubrd

2008 EIS

Business R\&D expenditures (\% of GDP)

besrd

2008 EIS

$R \& D$ personnel per labour force

rdpsnlab

2008 Eurostat

EPO patent applications (per million population)

epopc

2008 EPO

USPTO patent grants (per million population)

usptopc

2008 USPTO

Resident patents per capita

respat

2008 WIPO

Diffusion

Training enterprises as $\%$ of all enterprises

trainent

2005 Eurostat

CVT in \% of labour costs of all enterprises

cvtlabct

2005 Eurostat

ISO 900 certifications per capita

iso $9 \mathrm{kpc}$

2008 ISO 
Kutlaca Dj. and S. Radosevic Innovation Capacity in the South East Europe Region', In Thomas Döring and Dietmar Sternad (eds) Handbook of Doing Business in South East Europe, Palgrave Macmillan, 2011

Internet users per 10,000 inhabitants

Fixed broadband Internet subscribers (per 100 people)

ICT expenditures (\% of GDP) internet

fbbint

ictgdp
2008 ITU

2008 ITU

2006 Trendchart

Demand

Stock market capitalization in \% of GDP

stockmkt

2008 World

Bank

Domestic credit provided by banking sector (\% of GDP)

domcredi

2008 World

Bank

Share of FDI stock in GDP

fdigdp

2008 UNCTAD

Share of trade in GDP

tradegdp

2008 World

Bank

Index of patent rights

iprindex

2005 Pack

(2008)

Registered unemployment

unempl

2008 UNECE

Consumer price index

cpi

2008 UNECE

Note: CVT = Continuous Vocational Training; EPO = European Patent Office; FDI = Foreign Direct Investment; GDP =

Gross Domestic Product; ICT = Information and Communication Technology; ISO = International Organization for

Standardization; R\&D = Research \& Development; USPTO = US Patent and Trademark Office.

Source: The authors.

In the following sections of this chapter we analyse the position of SEE countries with respect to each of the four major components of their NIC.

Absorptive capacity for industrial upgrading 
Kutlaca Dj. and S. Radosevic Innovation Capacity in the South East Europe Region', In Thomas Döring and Dietmar Sternad (eds) Handbook of Doing Business in South East Europe, Palgrave Macmillan, 2011

\begin{abstract}
Absorptive capacity is the ability to absorb new knowledge and to adapt imported technologies. This capability is essential if catching-up economies are to grow and innovate. Indicators that measure absorptive capacity are: expenditures in education as a per cent of GDP; science and engineering graduates (percentage of population 20-29years old); population with $3^{\text {rd }}$-level education; participation in life-long learning; employment in medium/high-tech industries; and employment in high-tech services industries. Table 9.2 shows where SEE countries stand in relation to the EU-27 average. Percentages highlighted in bold indicate areas above EU average, while percentages highlighted in grey indicate those areas where SEE countries are significantly (more than 50 per cent) below EU average.
\end{abstract}

Table 9.2 Indicators of absorptive capacity, SEE countries as \% of EU average

SI $\quad$ HU GR TR BG RO HR SRB MK AL MN $\quad$ BIH

Expenditures in education as a \% of GDP

S\&E graduates (\% of $20-29$ population)

Population with 3rd-level education

Participation in life-long learning

Employment in medium/high-tech industries

Employment in high-tech services industries
104.6 $\quad \mathbf{1 0 4 . 8} 80.657 .783 .385 .7 \quad 82.182 .3 \quad 94.8 \quad 57.886 .2 \quad-$

102.4 $72.6061 .454 .485 .2118 .356 .785 .2-$

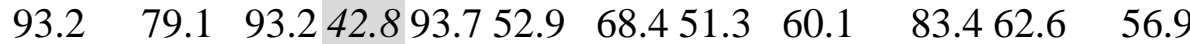

$\mathbf{1 4 4 . 8} 32.3 \quad 30.218 .814 .615 .6 \quad 22.913 .0$

137.9 $\quad \mathbf{1 4 0 . 4} 31.158 .577 .884 .9 \quad 70.158 .7 \quad-$

$73.0 \quad 81.6 \quad 79.639 .856 .037 .9 \quad 65.3 \mathbf{2 2 6 . 7}-$

Source: European Innovation Scoreboard (EIS) 2009; World Bank Development Indicators database (2009).

The absorptive capacity of South East Europe is clearly not an area of advantage when compared to the EU average. Only Slovenia has absorptive capacity indicators that are either above or close to the EU average. The majority of other countries are ranked below the EU average. The most pronounced differences are evident in life-long learning activities, where all SEE countries (except Slovenia) lag behind the EU average by more than 50 per cent. In terms of absorptive capacity, Greece does not differ from the rest of the region; this includes the low participation of its population in life-long learning. Also, the structure of its economy shows only a very small share of medium- and high-tech 
Kutlaca Dj. and S. Radosevic Innovation Capacity in the South East Europe Region', In Thomas Döring and Dietmar Sternad (eds) Handbook of Doing Business in South East Europe, Palgrave Macmillan, 2011

industries, with the share of high-tech services industries still at the levels of Slovenia and Hungary. As will become evident later on, weak life-long learning activities are accompanied by very weak firm-level training activities in most of the SEE economies.

\section{R\&D and innovation activities}

R\&D capability is important not only in generating new knowledge, but also as a mechanism to absorb it. Indicators that measure R\&D capability are: public R\&D expenditures (in per cent of GDP); business R\&D expenditures (in per cent of GDP); R\&D personnel per labour force; European Patents Office patent applications (per million population); US Patent and Trademark Office patent grants (per million population); and resident patents per capita.

Table 9.3 Indicators of R\&D capability, SEE countries as \% of EU average

SI HU GR TR BG RO HR SRB MK AL MN BIH

Public R\&D expenditures (\% of GDP)

Business R\&D expenditures (\% of GDP)

R\&D personnel per labour force
$86.6 \quad 67.261 .264 .249 .361 .274 .664 .27 .0 \quad-12.4-$

$88.443 .813 .224 .812 .414 .933 .15 .4 \quad 3.3-1.1-$

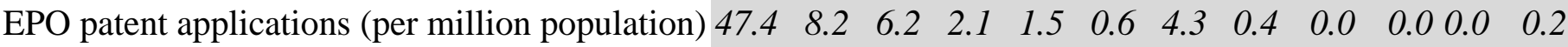

USPTO patent grants (per million population)

Resident patents per capita

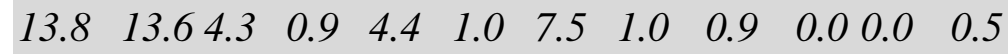

$64.5 \quad 30.132 .413 .914 .220 .134 .022 .97 .3 \quad-\quad-$

Note: EPO = European Patent Office; GDP = Gross Domestic Product; USPTO = US Patent and Trademark Office. Sources: European Innovation Scoreboard (EIS) (2009); EUROSTAT; EPO; USPTO.

As indicated by the large number of shaded (grey) areas in Table 9.3, knowledge generation capacity is a very weak component of SEE innovation capacity. SEE lies more than 50 per cent below the EU average in all factors except public funding of R\&D. The biggest gap is in patent activities - not only in world frontier technology patenting (EPO and USPTO patents), but also in terms of resident patenting per capita. With the exception of Slovenia, resident patenting per capita is below 50 per cent of the EU average in all other SEE economies. The business sector (again, with the exception of 
Kutlaca Dj. and S. Radosevic Innovation Capacity in the South East Europe Region', In Thomas Döring and Dietmar Sternad (eds) Handbook of Doing Business in South East Europe, Palgrave Macmillan, 2011

Slovenia) does not make a significant investment in R\&D either; here the gap also reveals that figures for SEE countries are more than 50 per cent below EU average. In terms of R\&D employment, Slovenia lies above the EU average, while Hungary, Greece, Croatia and Serbia are below the EU average. This gap, however, is much lower than in the case of outputs of R\&D activity. This suggests that the effectiveness of the R\&D systems of these economies is an issue that deserves further attention.

\section{Diffusion of innovation}

Diffusion is the key mechanism for reaping economic rewards from investment in R\&D and for increasing absorptive capacity. Indicators that measure diffusion include: training enterprises as a percentage of all enterprises; continuous vocational training (CVT) (in per cent of labour costs of all enterprises); ISO 9000 certifications per capita; Internet users per 10,000 inhabitants; fixed broadband Internet subscribers (per 100 people); and information and communication technology (ICT) expenditures (in per cent of GDP). Here the gap between the EU average and SEE is the smallest (see Table 9.4). This is to be expected for economies where the economic growth should be based on importing and on the diffusion of foreign technologies and knowledge. Also, this is an area where, at least in some indicators, several SEE economies are above the EU average. Slovenia and Hungary respectively rank best in the region in terms of diffusion capacity. Again, Greece ranks quite low, none of the indicators being above the EU average. SEE countries seem to lag least in ICT expenditures as a per cent of GDP (though data are not available for half of the countries). The difference is biggest in terms of fixed broadband Internet subscribers, which also reflects, partly, the low-income levels.

Table 9.4 Indicators of diffusion of innovation, SEE countries as \% of EU average

\begin{tabular}{|c|c|c|c|c|c|c|c|c|c|c|c|c|}
\hline & $\mathrm{SI}$ & $\mathrm{HU}$ & GR & TR & $B G$ & RO & $\mathrm{HR}$ & SRB & MK & $\mathrm{AL}$ & $\mathrm{MN}$ & $\mathrm{BIH}$ \\
\hline \multirow{2}{*}{$\begin{array}{l}\text { Training enterprises as \% of all enterprises } \\
\text { CVT (continuous vocational training) in \% of } \\
\text { labour costs of all enterprises }\end{array}$} & 121.7 & 81.7 & 35.0 & 47.9 & 48.3 & 66.7 & 143.3 & 60.9 & 31.6 & 33.2 & 42.0 & 110.8 \\
\hline & 125.0 & 118.8 & 37.5 & - & 68.8 & 68.8 & 81.3 & - & - & - & - & - \\
\hline ISO 9000 certifications per capita & 116.8 & 125.8 & 76.4 & 23.1 & 85.1 & 60.9 & 66.5 & 34.7 & 16.2 & 1.7 & 31.4 & 26.3 \\
\hline \multirow{2}{*}{$\begin{array}{l}\text { Internet users per } 10,000 \text { inhabitants } \\
\text { Fixed broadband Internet subscribers (per } \\
100 \text { people) }\end{array}$} & 88.9 & 93.4 & 68.9 & 54.9 & 55.5 & 46.0 & 80.6 & 71.7 & 66.3 & 38.1 & 75.5 & 55.4 \\
\hline & 88.1 & 72.8 & 55.9 & 32.5 & 46.2 & 48.6 & 49.4 & 25.6 & 37.0 & 8.5 & 41.7 & 20.8 \\
\hline ICT expenditures (\% GDP) & 90.0 & 169.5 & 83.0 & 77.3 & 120.1 & 93.6 & - & - & - & - & - & - \\
\hline
\end{tabular}

\section{Demand for innovation}

Demand for R\&D and innovation is the key economic mechanism that initiates value creation through $\mathrm{R} \& \mathrm{D}$, absorption and diffusion activities. Indicators that measure demand for R\&D and innovation are: the availability of finance (stock market capitalization in per cent of GDP); domestic credit provided by the banking sector; share 
Kutlaca Dj. and S. Radosevic Innovation Capacity in the South East Europe Region', In Thomas Döring and Dietmar Sternad (eds) Handbook of Doing Business in South East Europe, Palgrave Macmillan, 2011

of FDI (in GDP); competition (share of trade in GDP; index of patent rights); and macroeconomic stability (registered unemployment; consumer price index). We assume that the more developed the financial system, the better it can articulate demand for innovation, given equality of technological opportunities. Share of trade and foreign direct investments (FDI) in GDP are used as proxies for the intensity of competition, together with the index of patent rights. $<x e n>^{4}</$ xen $>$ We assume that macro-economic stability through extending the horizon for entrepreneurs promotes demand for innovation (Table 9.5).

Table 9.5 Indicators of demand for R\&D and innovation, SEE countries as \% of EU average

\begin{tabular}{lcccccccccccc}
\hline & $\mathrm{SI}$ & $\mathrm{HU}$ & $\mathrm{GR}$ & $\mathrm{TR}$ & $\mathrm{BG}$ & $\mathrm{RO}$ & $\mathrm{HR}$ & $\mathrm{SRB}$ & $\mathrm{MK}$ & $\mathrm{AL}$ & $\mathrm{MN}$ & $\mathrm{BIH}$ \\
\hline Stock market capitalization in \% of GDP & 56.8 & 31.7 & 67.0 & 42.3 & 46.8 & 26.3 & 101.9 & 64.1 & 22.8 & - & $\mathbf{1 5 4 . 3}$ & - \\
Domestic credit provided by banking sector & 61.3 & 56.5 & 76.4 & 36.8 & 46.8 & 28.7 & 52.6 & 26.9 & 29.9 & 47.3 & 57.0 & 41.0 \\
Share of FDI in GDP & 84.5 & $\mathbf{1 1 6 . 5}$ & 29.1 & 36.0 & $\mathbf{2 6 1 . 1}$ & $\mathbf{1 0 6 . 8}$ & $\mathbf{1 4 4 . 8}$ & 95.0 & $\mathbf{1 3 5 . 4}$ & 58.8 & $\mathbf{2 0 1 . 8}$ & $\mathbf{1 2 3 . 2}$ \\
Share of trade in GDP & $\mathbf{1 7 4 . 8}$ & $\mathbf{1 9 9 . 5}$ & 67.9 & 64.5 & $\mathbf{1 7 7 . 3}$ & $\mathbf{8 6 . 7}$ & $\mathbf{1 1 3 . 8}$ & $\mathbf{1 0 1 . 3}$ & $\mathbf{1 6 1 . 8}$ & 111.7 & 141.9 & 90.8 \\
Index of patent rights & 98.6 & $\mathbf{1 0 3 . 2}$ & 98.6 & 92.0 & $\mathbf{1 0 4 . 1}$ & 95.6 & 98.4 & 98.2 & 98.2 & - & 98.3 & - \\
Registered unemployment & $\mathbf{6 2 . 9}$ & 111.4 & 110.0 & 138.6 & 80.0 & 82.9 & 120.0 & 194.3 & 482.9 & 185.7 & 240.0 & 334.3 \\
Consumer price index & 103.4 & 109.5 & 101.9 & 122.2 & 120.3 & 111.0 & 103.7 & 121.9 & 104.8 & 100.3 & 107.9 & 106.6 \\
\hline
\end{tabular}
Sources: UNECE-EUROSTAT; UNCTAD; World Bank.

The overall picture in terms of demand (see Figure 9.5) is not so favourable as it is in terms of diffusion or absorption capacity, but it is better than it is in terms of knowledge generation capacity. Financial indicators (except FDI) show an undeveloped financial system, which does not generate pull for innovation. The situation is best in terms of FDI, as SEE economies have attracted FDI from developed EU countries, in particular from Germany, Austria and Italy. However, there is an issue as to whether FDI contributes to technology transfer, which we will address below. SEE economies are small and open economies, which have made attempts to attract foreign investors and hence have reformed their intellectual property rights regimes for both domestic and foreign innovators. A high FDI and trade openness further reinforces the importance of national innovation systems, generating synergies with trade and FDI partners (see below). On the demand side, macro-economic stability is generally much better than it used to be in the period of early transition. However, in comparison to the EU average, the SEE economies (except Slovenia) show higher unemployment rates and higher levels of inflation. These are indicators for economies that operate below full capacity and with significant cost pressures. Both of these factors are incentives for improving production capacity through new investments rather than innovation capability.

Overall, the analysis of the four components of innovation capacity shows that SEE lies far behind the EU average - with the exception of Slovenia, which ranks very close to or at EU average. The countries in the region perform worse than the EU average in the generation of new knowledge, are better in terms of diffusion and are best in terms of absorptive capacities. A better ranking in terms of absorptive capacities is expected for 
Kutlaca Dj. and S. Radosevic Innovation Capacity in the South East Europe Region', In Thomas Döring and Dietmar Sternad (eds) Handbook of Doing Business in South East Europe, Palgrave Macmillan, 2011

catching-up economies, and it seems that policy makers should focus on significantly improving diffusion and demand capacities, both of which are essential for employing absorptive capacities. Knowledge generation capacities cannot improve without positive reinforcements from the other three components. Factors of demand for innovation and R\&D are, relatively speaking, better than knowledge generation, but still below absorptive and diffusion capacities. Current policies in the majority of SEE countries are largely focused on R\&D capacities, while neglecting the other components. However, our framework suggests that the effects of R\&D policies will ultimately fail unless they are supported by positive signals from the other three components. This calls for new approaches to policy, which are primarily concerned with interactions in innovation system and which therefore go beyond narrowly defined R\&D policies.

\section{Assessing national innovation capacity in SEE}

So far we have shown a cross-section picture of innovation capacity in the SEE region. Following a procedure based on that developed by Zinnes et al. (2001) and Porter et al. (2002), we will continue with standardizing the data, multiplying them by assigned weights and adding together all the resulting products. In this way we construct aggregate values for each of the four components of national innovation capacity. By summing up the values of the four components we calculate the aggregate national innovation capacity index. We assign equal weights to all indicators, except for a few cases where indicators measure similar aspects of components - in those cases we reduce the weight of individual indicators. In measuring absorptive capacity, each of the six indicators carries one-sixth of the weight. For R\&D supply we assign one-fifth to each of the indicators, since we treat US and European patent office patents as one single indicator, with half a weight assigned to each of them. We adopt the same procedure to calculate diffusion capacity. We assign one-fifth to each of the five indicators, since we treat Internet use and personal computers (PCs) per capita as one single indicator, with half a weight assigned to each. Unemployment and consumer price indices are inversely proportional to the NIC index. We change the signs of these two indicators to make them, like other indicators, positively proportional. The summary innovation capacity index is the simple summation of the four components. Table 9.6 and Figure 9.2 show aggregate values of the NIC index based on this methodology.

Table 9.6 National innovation capacity, SEE countries

\begin{tabular}{llllllllll}
\hline & SI & HU & HR & BG & GR & SRB & RO & MK & TR \\
\hline Aggregate & & & & & & & & & \\
NIC & 4.552 & 2.613 & 0.751 & 0.053 & -0.682 & -0.936 & -1.333 & -1.850 & -3.167
\end{tabular}


Kutlaca Dj. and S. Radosevic Innovation Capacity in the South East Europe Region', In Thomas Döring and Dietmar Sternad (eds) Handbook of Doing Business in South East Europe, Palgrave Macmillan, 2011

Absorptive capacity 1.309 $0.504-0.434 \quad 0.010$ $-0.309 \quad 0.055$ $-0.069$ $0.067-1.133$

$\mathrm{R} \& \mathrm{D}$ supply 1.845 0.367 0.258 $-0.492$ 0.076 $\begin{array}{llll}-0.230 & -0.457 & -0.908 & -0.459\end{array}$

Diffusion

$$
0.906 \quad 1.276
$$

Demand

Note: Data for Albania and for Bosnia and Herzegovina are insufficient for a calculation of aggregate values of the four dimensions and of the overall value of NIC.

Source: Calculation of NIC according to methodology in Radosevic (2004).

Figure 9.2: National innovation capacity of the SEE countries

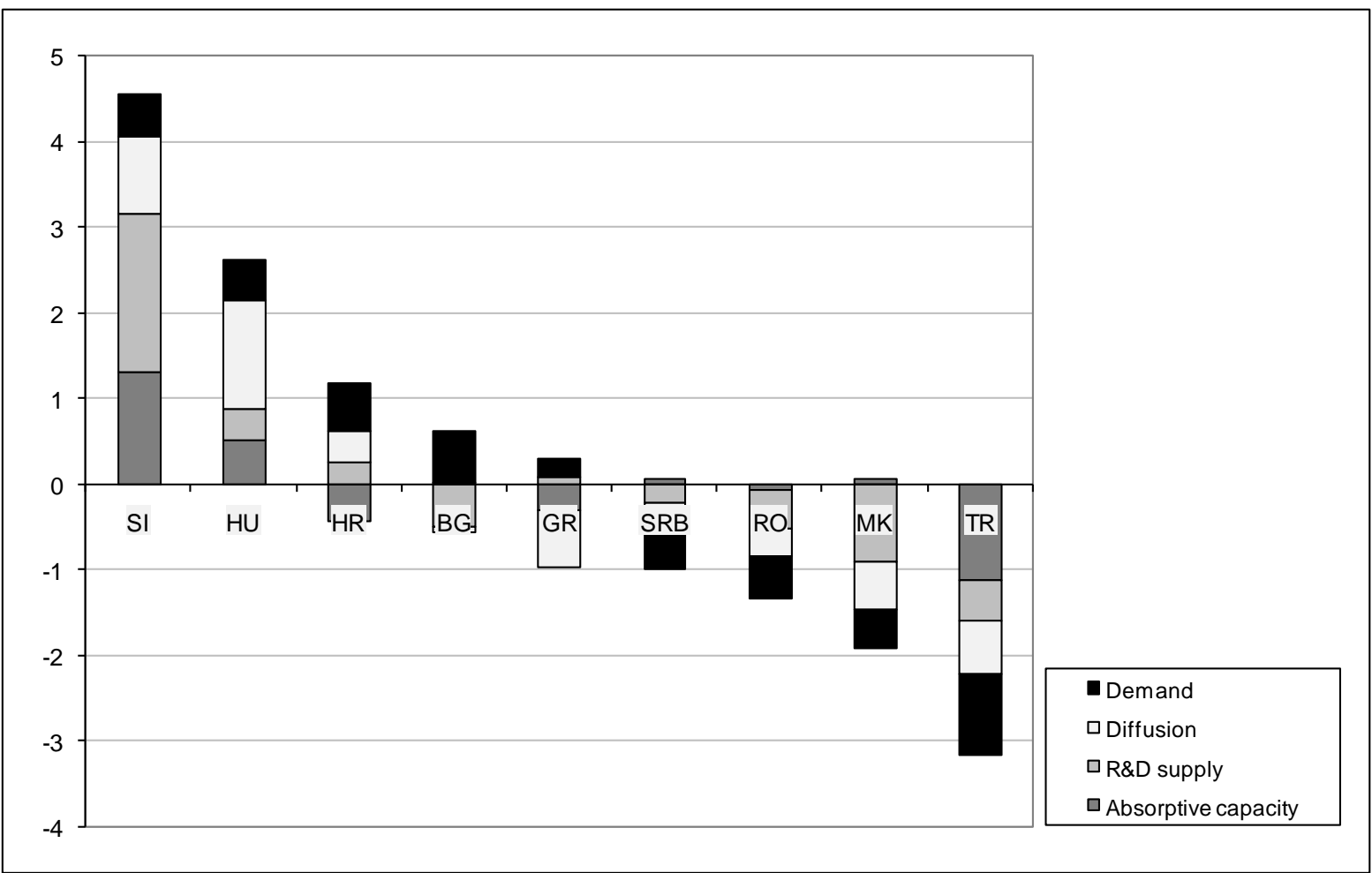

Source: Calculation of NIC according to methodology in Radosevic (2004).

The aggregation of different dimensions of innovation capacity into the NIC index reveals considerable differences in innovation capacity between countries, which is to be expected given the analysis above. Slovenia emerges as the clear regional leader. It 
Kutlaca Dj. and S. Radosevic Innovation Capacity in the South East Europe Region', In Thomas Döring and Dietmar Sternad (eds) Handbook of Doing Business in South East Europe, Palgrave Macmillan, 2011

is the only SEE economy which ranks around the EU average in the majority of NIC indicators. In terms of innovation capacity in the region, Slovenia is followed by Hungary, Croatia, Bulgaria and Greece. These countries are above the SEE average. The national innovation capacities of Serbia, Romania, FYR of Macedonia and Turkey are least developed. If data were available for Bosnia and Herzegovina and for Albania, we suspect that these economies would belong to the lower segment of SEE countries. These results are in line with expectations when one looks at the individual components of NIC, but they are not identical to rankings by the European Innovation Scoreboard.

The European Innovation Scoreboard (EIS) is an alternative composite indicator, which has become an established measure for innovation in the EU. EIS 2009 presents the current innovation performance in Bulgaria, Greece, Hungary, Romania, Slovenia, Croatia, Turkey and Serbia. Most of the innovation scoreboard data are still not available for other SEE countries. The Summary Innovation Index (SII), as a composite of twentynine indicators representing innovation performance in the observed countries. According to SII and compared with the EU-27 average, different SEE countries are classified as being at different stages of innovation development (EIS, 2009) (see Table 9.7).

Table 9.7: SEE economies based on the European Innovation Scoreboard index (SII)

Innovation follower Slovenia

Moderate innovator

Catching-up countries*
Greece $(\mathrm{SII}=0.370)$, Hungary $(\mathrm{SII}=0.328)$

Bulgaria $(\mathrm{SII}=0.231)$, Croatia $(\mathrm{SII}=$ $0.286)$, Romania $(\mathrm{SII}=0.294)$, Serbia $(\mathrm{SII}=$ $0.227)$

*: No data for SII is available for Albania, for Macedonia and for Bosnia and Herzegovina, but these countries can confidently be grouped under the catchingup countries category.

Source: Based on European Innovation Scoreboard (2009).

As was shown above, the ranking of countries differs when they are grouped on the basis of alternative composite indicators of NIC. Hence the question to be asked is: what does EIS actually measure? We would argue that EIS indicates the degree to which the growth of economies is based on the world frontier innovation, not necessarily on its own innovation capacity, which should include innovation activities typical for countries behind the technological frontier. The EIS was originally designed to measure the innovativeness of EU economies in relation to the technology leader, the United States. Hence this composite indicator has a built-in bias towards technology effort that takes 
Kutlaca Dj. and S. Radosevic Innovation Capacity in the South East Europe Region', In Thomas Döring and Dietmar Sternad (eds) Handbook of Doing Business in South East Europe, Palgrave Macmillan, 2011

place at the world's technological frontier. However, SEE countries are countries operating behind the technological frontier, with their growth largely based on imported technology and on its adaptation and improvements. Therefore our composite indicator seems to be a better approximation of the type of technology effort that takes place in SEE countries.

Inevitably, ranking countries on the basis of two different composite indicators will lead to different results. The biggest difference between NIC and EIS lies in the ranking of Greece. According to EIS, Greece ranks second among the SEE countries, while according to our NIC it only ranks fifth. Greece ranks much better when its innovativeness is measured by the extent to which the country relies on world frontier innovation activities than when it is measured by NIC. However, having a high score based on world frontier innovation activities does not necessarily mean that a country will grow faster, or that its GDP per capita will necessarily be higher. Countries should grow on the basis of the type of technology effort that is appropriate to their current and future level of development. For example, countries behind the technological frontier should grow at the highest rate if they improve their technology imitation and absorption activities. A high share of growth based on world frontier activities, which is combined with a low share of imitation and activities behind the world frontier, may indicate imbalances in the national innovation system rather than being an appropriate model of growth.

In addition, EIS contains twenty-nine indicators while NIC contains twenty-five, of which only nine are identical. Among others, EIS contains more indicators that measure activities associated with world frontier technology activities like doctorate graduates, venture capital, technology balance of payment and export of knowledgeintensive services. On the other hand, NIC leans more towards measuring activities behind the technological frontier like resident patents and ISO 9000-certificates. In addition, differences also result from the general availability of indicators, which is much more restricted for some SEE countries.

Figure 9.3: Relationship between national innovation capacity index (NIC) and GDP per capita at purchasing power parity (GDPpc PPP) (2008) 
Kutlaca Dj. and S. Radosevic Innovation Capacity in the South East Europe Region', In Thomas Döring and Dietmar Sternad (eds) Handbook of Doing Business in South East Europe, Palgrave Macmillan, 2011

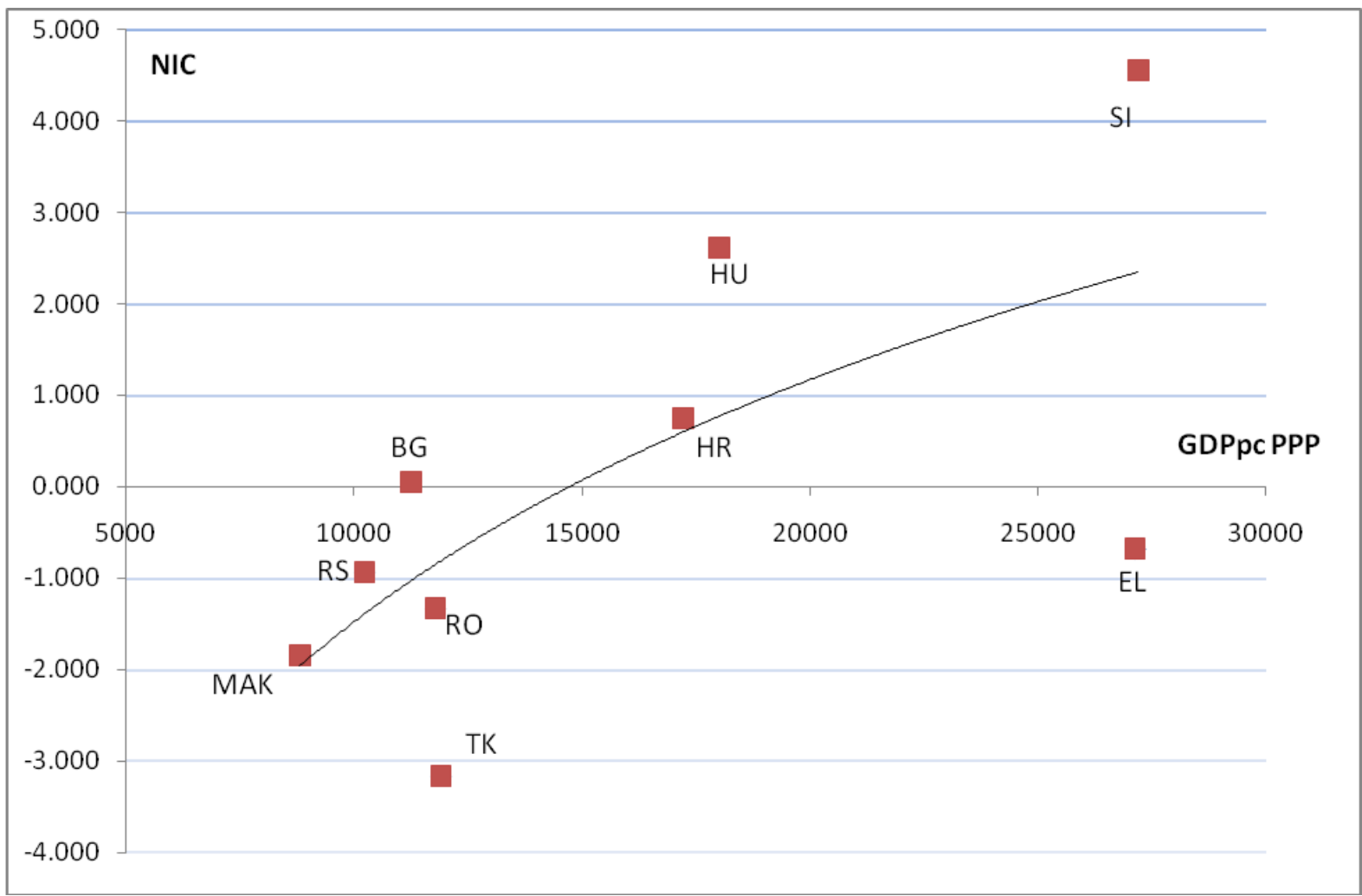

Source: Authors for NIC; World Bank Development Indicators database for GDP per capita at purchasing power parity.

On the basis of the analysis above, we will now explain the relevance of our approach for understanding industrial upgrading in SEE countries. First, NIC indicates that the extent to which countries grow is based on innovation (albeit not necessarily on world frontier innovation activity). Current NIC, however, is not necessarily reflected in current growth. So NIC indicates potential for technological upgrading as well as the degree to which current levels of development are a reflection of innovation-based activities. For example, Greece has a much higher income per capita, but its innovation capacity is much lower than would be expected (see Figure 9.3). This simply points to the fact that the source of the Greek economic growth is in activities that are not based on technology, but in services that do not have much technological content. On the other hand, Slovenia has a higher NIC than its current income would predict, which suggests that this country has greater potential for growth based on technology catch-up. Alternatively, one could argue that its national innovation system (NIS) is not contributing to growth as would be expected. In the case of other countries these mismatches are visibly lower, which suggests that their future growth would require more investment in innovation activities. However, it is important to note that the sample of countries taken here is far too small for broad generalizations. Nevertheless, these seem to be intuitively very indicative conclusions. In addition, current levels of NIC may affect 
Kutlaca Dj. and S. Radosevic Innovation Capacity in the South East Europe Region', In Thomas Döring and Dietmar Sternad (eds) Handbook of Doing Business in South East Europe, Palgrave Macmillan, 2011

growth with sometimes significant delay - hence this relationship can be properly understood only in a longitudinal perspective.

SEE countries are operating behind the technological frontier in terms of knowledge generation and sources of growth, which are largely based on the acquisition and adoption of imported technologies. Thus their growth will be strongly dependent on how they are combining their internal process of technology accumulation with international technology import and export. We now turn to these issues, which are of equal importance for SEE.

\section{International technology integration in SEE}

The current period provides a new and historic opportunity for the SEE region to integrate into the wider European economy. This should facilitate the catching up of this region with the EU core. From an industry upgrading perspective, countries can be integrated through production (industrial networks), but also through technology - or through knowledge-intensive networks. In this latter case we can speak of technology integration, by which we mean integration into the process of knowledge generation and diffusion across international borders. Obviously there is an overlap between production and technology integration, as production integration via foreign direct investment (FDI) and sub-contracting linkages may involve a significant degree of joint knowledge generation and exchange. Technology and knowledge integration are most visible in the field of $R \& D$ through the involvement in international $R \& D$ projects, through external funding of $R \& D$ or through the education of nationals abroad. This upstream integration at the level of $R \& D$ and human capital can be quite different to downstream integration at the level of trade and FDI. For example, Slovenia is highly integrated at the upstream or R\&D level, but much less so at the level of FDI.

Subsequently we discuss first the integration at upstream or R\&D level. We have recently seen an increasing integration of South East European R\&D systems into EU R\&D project networks. Table 9.8 shows that there are still very big differences in that respect between individual SEE countries, Greece and Slovenia clearly lying much ahead of the rest of the region. EU co-funding in these two countries is above the EU average, while per capita EU funding is several times lower than the average in other SEE countries. This is partly a reflection of much less developed R\&D systems in these countries, as well as the effect of the 'early start' of these countries as regards the Seventh Framework Programme (FP7).

Table 9.8: SEE involvement in Seventh Framework Programme (FP7) projects: European Commission's contributions and requested contributions in FP7

Applicant-requested EC Participant EC contribution Share of signed financial contribution in EUR in EUR (only in signed contracts in 
Kutlaca Dj. and S. Radosevic Innovation Capacity in the South East Europe Region', In Thomas Döring and Dietmar Sternad (eds) Handbook of Doing Business in South East Europe, Palgrave Macmillan, 2011

(cumulative, not only of signed agreements) contracts of calls closed in requested reference year)

\section{All FP7 PER 1MN POPULATION}

\section{All FP7 PER 1MN POPULATION}

Greece

Slovenia

Bulgaria

Croatia

Montenegro

Serbia

FYR of Macedonia 3.68

Romania

Turkey

Albania

0.48

1.01
28.99

20.36

1.38

2.24

2.65

$72 \%$

2.08

$57 \%$

Bosnia and

Herzegovina
0.37 
Kutlaca Dj. and S. Radosevic Innovation Capacity in the South East Europe Region', In Thomas Döring and Dietmar Sternad (eds) Handbook of Doing Business in South East Europe, Palgrave Macmillan, 2011

Average EU-27

countries

32.49

Source: eCORDA, 8 June 2010, derived from Rivera León and Reid (2010).

We can expect that the SEE countries' R\&D systems will become highly integrated into the European Research Area. This should have positive effects in terms of dynamism and excellence in R\&D, as many countries' R\&D groups will be 'plugged' into EU R\&D networks. However, these effects by themselves will not ensure the relevance of these countries' R\&D systems to their local economies (Radosevic, 2009). As the best, if R\&D groups become integrated into EU networks, the gap between them and the local business sectors may widen. The situation of SEE may resemble the situation in Greece, where a competent R\&D system has relatively limited links to the domestic business sector.

This orientation towards EU funding has made R\&D systems of SEE already quite dependent on EU sources. Table 9.9 shows that the share of foreign funding of R\&D is by far the highest in Greece, but also Bulgaria, Hungary and, surprisingly, Croatia have already recorded high shares. If these early trends continue for new member states as well as for candidate states, it is to be expected that SEE countries will (just like Greece) be highly dependent on EU funding, which will have its own positive as well as negative effects. As was already pointed out, positive effects may include increasing international excellence, but not necessarily also increasing local relevance. It is significant that even countries like Serbia, which joined the Seventh Framework Programme quite recently, will soon reach EU average in the share of foreign R\&D funding.

Table 9.9: External funding of R\&D: Total intramural R\&D expenditure (GERD) by source of funds, percentage of GDP

\begin{tabular}{lllll}
\hline & $\begin{array}{l}\text { GERD by } \\
\text { source of } \\
\text { funds: All } \\
\text { sectors }\end{array}$ & $\begin{array}{l}\text { GERD by } \\
\text { source of } \\
\text { funds: Abroad }\end{array}$ & $\begin{array}{l}\text { Share of } \\
\text { GERD } \\
\text { financed from } \\
\text { abroad }\end{array}$ & $\begin{array}{l}\text { Reference } \\
\text { year }\end{array}$ \\
\hline EU average (27 countries) & 1.9 & 0.17 & $8.9 \%$ & 2008 \\
Bulgaria & 0.48 & 0.04 & $8.3 \%$ & 2007 \\
Greece & 0.59 & 0.11 & $18.6 \%$ & 2005
\end{tabular}


Kutlaca Dj. and S. Radosevic Innovation Capacity in the South East Europe Region', In Thomas Döring and Dietmar Sternad (eds) Handbook of Doing Business in South East Europe, Palgrave Macmillan, 2011

$\begin{array}{lllll}\text { Hungary } & 1 & 0.09 & 9.0 \% & 2008 \\ \text { Romania } & 0.58 & 0.02 & 3.4 \% & 2008 \\ \text { Slovenia } & 1.66 & 0.09 & 5.4 \% & 2008 \\ \text { Croatia } & 0.9 & 0.07 & 7.8 \% & 2008 \\ \text { Turkey } & 0.72 & 0 & & \\ \text { Serbia } & 0.69 & 0.04 & 6.7 \% & 2007\end{array}$

Source: EUROSTAT database, September 2010; data for Serbia from Serbian Statistical Office.

The Europeanization of R\&D systems is accompanied by an increasing desire of students to study abroad, which can be classified either as 'brain drain' or as 'brain gain', or indeed as 'brain circulation'. It seems that this process is advancing at a somewhat slower rate than the increase in foreign funding of R\&D. Table 9.10 shows that Albania is the major 'export' destination in this respect, while Greece and FYR of Macedonia are around the average level of the EU-27. Other SEE countries are lagging significantly behind. This can be explained by a variety of factors related to travel restrictions, size of countries as well as quality of life and living standards in individual countries.

Table 9.10: Foreign students in tertiary education (ISCED 5-6) by country of citizenship, percentage of total population

$\begin{array}{lll}\text { Country of citizenship } & \begin{array}{l}\text { Number of students from country } \\ \text { in EU-27, year 2007 }\end{array} & \begin{array}{l}\% \text { of total } \\ \text { population }\end{array}\end{array}$

Albania

18,965

0.603

Greece

34,878

0.324

FYR of Macedonia

6,205

0.304 
Kutlaca Dj. and S. Radosevic Innovation Capacity in the South East Europe Region', In Thomas Döring and Dietmar Sternad (eds) Handbook of Doing Business in South East Europe, Palgrave Macmillan, 2011

Bulgaria

Croatia

Bosnia and Herzegovina

Serbia and Montenegro

Slovenia

Romania

Hungary

Turkey

EU27
21,212

0.278

9,126

0.216

7,258

0.192

9,617

0.121

2,309

0.114

20,074

0.093

7,377

0.075

37,588

0.054

$1,709,775$
0.349

Source: EUROSTAT database, September 2010; data for Serbia from Serbian Statistical Office.

While external conditions undoubtedly play an important role, internal conditions for retaining local talent are probably even more important. Data collected within the World Economic Forum (WEF) Global Competitiveness Report probed into this area by asking respondents about local conditions (Table 9.11). SEE countries vary greatly in terms of the existence of conditions that would prevent the 'brain drain'. On the one hand, there are Slovenia and Montenegro, while Serbia and Bosnia and Herzegovina are at the other extreme and the majority of SEE countries are at the lower end of the spectrum. On the positive side, these divergences represent great opportunities for intraSEE education and skills migrations.

Table 9.11 Evaluation of conditions for the prevention of 'brain drain' from country, World Economic Forum (WEF), 2010 
Kutlaca Dj. and S. Radosevic Innovation Capacity in the South East Europe Region', In Thomas Döring and Dietmar Sternad (eds) Handbook of Doing Business in South East Europe, Palgrave Macmillan, 2011

'Does your country retain and attract talented people?' [1 = no, the best and brightest normally leave to pursue opportunities in other countries;

7 = yes, there are many opportunities for talented people within the country], 2009-10 weighted average

SCORE RANK

Slovenia

48

Montenegro

Turkey

90

Hungary

$2.7 \quad 99$

Greece

$2.7 \quad 103$

Albania

$2.7 \quad 107$

Romania

$2.4 \quad 116$

Croatia

FYR of Macedonia

$2.2 \quad 126$

Bulgaria

Serbia

136

Bosnia and Herzegovina

2.0

138 Source: Schwab (2010).

To summarize, results from the analysis of selected data suggest that SEE has already become quite integrated into the EU R\&D networks, with ambiguous effects on 
Kutlaca Dj. and S. Radosevic Innovation Capacity in the South East Europe Region', In Thomas Döring and Dietmar Sternad (eds) Handbook of Doing Business in South East Europe, Palgrave Macmillan, 2011

its R\&D system. Also, EU integration has generated new opportunities in terms of migration of skilled people; however, these opportunities still vary widely between different countries.

This picture of upstream integration needs to be complemented by a picture of downstream integration (integration of SEE at the level of trade and production networks). Table 9.12 summarizes the situation by distinguishing between producerdriven and buyer-driven value chains. Producer-driven value chains are based on multinational companies' direct foreign investments, which are closely linked to intensifying trade both in finished products and in semi-finished parts (network trade). Buyer-driven value chains are largely of the non-equity type - like sub-contracting, which is typical for instance for the clothing industry. Table 9.12 shows that FDI-driven networks and related network trade are characteristic of Hungary and Slovenia. Other SEE countries are largely excluded from producer-driven networks or network trade relationships. However, these countries (for example Albania, Bulgaria, Romania or Macedonia) are connected with the EU through sub-contracting linkages. This is largely cost-driven sub-contracting, which is very much unlike producer-driven networks, where local skills and technological knowledge play a more important role. Croatia and Serbia are not clearly integrated into either of these two forms of industrial networks.

Table 9.12: Network relationships of SEE countries by type of production networks

\begin{tabular}{|c|c|c|c|c|}
\hline \multirow[t]{2}{*}{$\begin{array}{l}\text { Type of } \\
\text { network } \\
\text { relationship }\end{array}$} & \multicolumn{2}{|c|}{$\begin{array}{l}\text { Producer-driven value chains } \\
\text { (largely equity relationships) }\end{array}$} & \multicolumn{2}{|c|}{$\begin{array}{l}\text { Buyer-driven value chains } \\
\text { (largely sub-contracting) }\end{array}$} \\
\hline & $\begin{array}{l}\text { FDI stock in } \\
\text { manufacturing } \\
\text { per capita }(\$) \\
(2003)\end{array}$ & $\begin{array}{l}\text { Networks' } \\
\text { exports per } \\
\text { capita }(\%) \\
(2003)\end{array}$ & $\begin{array}{l}\text { Share of } \\
\text { clothing export } \\
\text { in manufactured } \\
\text { export }(\%) \\
(2003)\end{array}$ & $\begin{array}{l}\text { Average annual } \\
\text { growth rate of } \\
\text { clothing export in \% } \\
\text { (1996-2003) }\end{array}$ \\
\hline Hungary & 1,694 & 1,847 & 4.1 & 3.8 \\
\hline Slovenia & 824 & 1094 & 3.5 & -7.5 \\
\hline Croatia & 694 & 69 & 15.5 & -0.9 \\
\hline
\end{tabular}


Kutlaca Dj. and S. Radosevic Innovation Capacity in the South East Europe Region', In Thomas Döring and Dietmar Sternad (eds) Handbook of Doing Business in South East Europe, Palgrave Macmillan, 2011

\begin{tabular}{l|ll|ll} 
Bulgaria & 428 & 22 & $\mathbf{3 4 , 0}$ & $\mathbf{2 7 , 0}$ \\
Romania & 262 & 59 & $\mathbf{2 9 . 8}$ & 18.5 \\
$\begin{array}{l}\text { Serbia and } \\
\text { Montenegro }\end{array}$ & 217 & 15 & 14.5 & -4.4 \\
FYROM & 60 & 11 & $\mathbf{4 4 . 9}$ & 7.3 \\
Albania & & $\mathbf{4 1 . 1}$ & 17.2 \\
Turkey & & $\mathbf{2 6 . 3}$ & 7.3 \\
\hline
\end{tabular}

Source: Based on Broadman (2005).

From a developmental perspective, upstream and downstream types of integration should complement each other. This is more likely to happen in the case of countries that are integrated through producer-driven networks than in those integrated through buyerdriven networks. Producer-driven networks are more technologically driven, or at least they contain significantly higher potential for further industrial upgrading as well as links with $R \& D$ and innovation activities. For countries characterized by buyer-driven networks this is a much bigger challenge.

\section{Conclusion}

This chapter has demonstrated major differences between SEE countries in terms of their innovation capacities. In the context of EU integration and international business this represents a specific set of constraints as well as opportunities. In several respects, South East Europe is the most complex region in contemporary Europe (Radosevic, 2009).

From an international business perspective, it represents a complex institutional fabric of different degrees of integration into the EU economy, as well as a variety of different institutional arrangements in terms of intra-regional trade and cooperation. On the other hand, a diversity of 'production functions' in the region - in part due to differences in labour costs and in productivity levels - offers opportunities for intra-regional FDI and sub-contracting arrangements. Despite its close proximity to core EU economies, SEE remains only very partially integrated into the EU economy. Improvements in the national innovation systems of SEE countries have mainly occurred through vertical linkages on the upstream (through the integration of R\&D into the European Research Area) and on the downstream (through positive direct effects of FDI and through sub- 
Kutlaca Dj. and S. Radosevic Innovation Capacity in the South East Europe Region', In Thomas Döring and Dietmar Sternad (eds) Handbook of Doing Business in South East Europe, Palgrave Macmillan, 2011

contracting linkages) sides. Whether these vertical linkages will be enhanced and whether they will mutually interact will also depend on the activities of local governments and of other stakeholders. The capacity to work with foreign investors in enhancing both local and external linkages remains to be developed.

\section{Notes}

$<$ en $><$ label $>1</$ label $>$ For the purpose of this chapter and from the perspective of European integration and of the European Research Area, the expression 'SEE' will cover the four Western Balkan countries (Albania; Bosnia and Herzegovina; Montenegro; and Serbia), three EU candidate countries (Croatia; FYR of Macedonia; and Turkey) and five EU Member states (Bulgaria; Greece; Hungary; Romania; and Slovenia).</en> $<$ en $><$ label $>2</$ label $>$ Data are not available for Bosnia and Herzegovina, FYR of Macedonia, Albania and Montenegro. However, given other available indicators for these economies, it is safe to conclude that these economies rank at the bottom of the EU scale in terms of their innovation capacity. $</ e n>$ $<$ en $><$ label $>3</$ label $>$ For a discussion of composite indicators, see OECD (2008), and for their critique, see Grupp and Mogee (2004). $</$ en $>$ $<$ en $><$ label $>4</$ label $>$ The index of patent rights is constructed by Ginarte and Park (1997). The G-P index is constructed as a scoreboard of five features of patent protection: (1) extent of coverage; (2) membership in international patent agreements; (3) provisions for loss of protection; (4) enforcement mechanism; and (5) duration of protection. Each of these categories is broken down into several sub-components and weighted in such a way that each category ranges in value from 0 to 1 . These categories are summed up as unweighted components, so the index value ranges from 0 to 5 . Higher values of the index indicate stronger levels of protection. Values used in this chapter are recalculations prepared by Park (2008). $</$ en $>$

\section{References}

Broadman, H. G. (ed.) (2005) From Disintegration to Reintegration: Eastern Europe and the Former Soviet Union in International Trade (Washington DC: The International Bank for Reconstruction and Development/The World Bank).

EIS (2009) European Innovation Scoreboard (EIS) 2009 - Comparative Analysis of Innovation Performance, PRO INNO Europe paper no. 15 (Brussels: European Union).

GFF (2006) Gesellschaft zur Förderung der Forschung (ed.), Research and Development in South East Europe (Wien, Graz: Neuer Wissenschaftlicher Verlag GmbH).

Ginarte, J. C. and Park, W. G. (1997) 'Determinants of Patent Rights: A Cross-National Study', Research Policy, 26, 283-301. 
Kutlaca Dj. and S. Radosevic Innovation Capacity in the South East Europe Region', In Thomas Döring and Dietmar Sternad (eds) Handbook of Doing Business in South East Europe, Palgrave Macmillan, 2011

Grupp, H. and Mogee, M. E. (2004) 'Indicators for National Science and Technology Policy: How Robust Are Composite Indicators?', Research Policy, 33, 1373-1384.

Kutlača, D. (2006) 'S\&T System of Serbia: Between Survival and Restructuring', International Conference 'Why Invest in Science in South Eastern Europe', UNESCO Regional Bureau for Science and Culture in Europe (BRESCE), UNESCO Office in Venice, Proceedings of the International Conference and High Level Round Table, Ljubljana, 28-29 September, 131-139.

Lundvall, B. A. (ed.) (1992) National Systems of Innovation: Towards a Theory of Innovation and Interactive Learning (London: Pinter).

OECD (2002) The Measurement of Scientific and Technological Activities - Frascati Manual: Proposed Standard Practice for Surveys of Research and Experimental Development (Paris: OECD).

OECD (2005) The Measurement of Scientific and Technological Activities - Oslo Manual: Guidelines for Collecting and Interpreting Innovation Data, 3rd edn (Paris: OECD).

OECD (2007) Main Science and Technology Indicators, vol. 1 (Paris: OECD).

OECD (2008) Handbook on Constructing Composite Indicators: Methodology and User Guide (Paris: OECD).

Park, W. G. (2008) 'International Patent Protection: 1960-2005', Research Policy, 37, 761-766.

Radosevic, S. (2004) 'A Two-Tier or Multi-Tier Europe? Assessing the Innovation Capacities of Central and East European Countries in the Enlarged EU', Journal of Common Market Studies, 42, 3, 641-666.

Radosevic, S. (2009) 'Research and Development and Competitiveness, and European Integration of South Eastern Europe', Euro-Asia Studies, 61, 621-650.

Rivera León, L. and Reid, A. (2010) Participation of South-East European Countries in the Competitive Funding Programmes for Research in the European Commission, Report to UNESCO-BRESCE, Technopolis group, July.

Schwab, K. (ed.) (2010) The Global Competitiveness Report 2010-2011 (Geneva: World Economic Forum).

Teece, D. J. (2000) Managing Intellectual Capital: Organizational, Strategic, and Policy Dimensions (Oxford: Oxford University Press). 
Kutlaca Dj. and S. Radosevic Innovation Capacity in the South East Europe Region', In Thomas Döring and Dietmar Sternad (eds) Handbook of Doing Business in South East Europe, Palgrave Macmillan, 2011

WEF (2010) The Lisbon Review 2010 - Towards a More Competitive Europe? (Geneva: World Economic Forum).

Zysman, J. and Schwartz, A. (eds) (1998) Enlarging Europe: The Industrial Foundations of a New Political Economy (Berkeley: Institute for International Studies). 